DOI https://doi.org/10.30525/978-9934-26-173-2-2

\title{
ПСИХОЛОГІЧНІ ОСОБЛИВОСТІ ПОЗИТИВНОГО СТАВЛЕННЯ ОСОБИСТОСТІ ДО ШЛЮБУ
}

\author{
Федоренко А. Ф. \\ кандидат психологічних наук, дочент, \\ доцент кафедри загальної і соціальної психологї \\ Національний педагогічний університет імені М. П. Драгоманова
}

\section{Ханецька T. I.}

кандидат психологічних наук, доцент, дочент кафедри психосоматики та психологічної реабілітації Національний педагогічний університет імені М. П. Драгоманова м. Київ, Україна

Позитивне ставлення до шлюбу відіграє провідну роль у відчутті щастя самою особистістю. Факт задоволеності людиною стосунками в сім’ї, їх стабільністю та міцністю надзвичайно сильно залежить від соціальних та економічних умов в самій родині та у суспільстві загалом. В сучасному світі дуже багато змін, які негативно впливають на зміцнення сімейної взаємодії, таких як: міграція міжнародна та всередині країни, урбанізація, швидка та легка мобільність, майже повна автономність та анонімність особистісного життя у місті, коли особистість може не створювати близьких стосунків загалом, науковотехнічний прогрес, агресивна реклама, вплив масової культури, ослаблення дії релігійних та культурних норм на життя людини, політичні та соціальні кризи сучасного суспільства, напруженість особистого життя тощо. Багато сімей та окремих особистостей не в змозі витримати усіх цих навантажень, що призводить до різних негативних психічних явищ, психологічних зривів, розладу сімейного життя, зрад та розлучень. При всьому цьому сама цінність сім'ї не зменшується, навпаки, зростає ії значення в психологічній підтримці один одного. Відчутною стає відсутності альтернатив сім'ї та ії постійний рух в усьому світі на більш високий рівень розвитку.

Проведений нами аналіз літературних джерел вказує на те, що на сьогодні недостатньо розроблені питання, які мають безпосереднє відношення до якості створення сім'ї та стосунків. Дослідження сімей в основному стосуються вивчення окремих сторін якості шлюбу, таких як 
стабільність та стійкість, сумісність подружжя між собою, роль сім’ї в суспільстві тощо [1; 5].

Лише деякі дослідники зверталися до проблеми вивчення сімейних стосунків з точки зору якості шлюбу, його задоволеності. Розглядаючи різні підходи до розуміння поняття «задоволеність шлюбом», нами було визначено, що в психологічній науці не існує єдиної концепції розуміння понятійного апарату сімейної психології, тобто різні автори вживають різноманітні терміни для позначення одних і тих же понять та процесів, що проходить сім'я. Крім того дослідники виділяють різні фактори, що мають вплив на задоволеність шлюбом, на позитивне до нього ставлення [4;6].

Створюючи сім'ю, особистість має на меті наповнити своє власне життя абсолютно новим та позитивним змістом, сподіваючись, що після одруження сімейна взаємодія і самі стосунки зміняться, а життя загалом стане кращим та цікавішим. Часто такого роду сподівання лежать в основі створення майбутньої сім’ї. І коли вони починають руйнуватися, з'являється реальна загроза існування шлюбу. Соціологія інтерпретує поняття задоволеності шлюбом, як характеристику суб'єктивної оцінки людиною, кожним з подружжя, суті та характеру їхніх стосунків. Сім'я тут розглядається з точки зору іiі власних постійних змін, аналогічним процесам, що відбуваються у малій групі. Різні автори вживають такі синонімами терміну «задоволеність шлюбом» як: «позитивне ставлення до шлюбу», «сумісність подружжя», «успішність шлюбу», «згуртованість сім’ї» тощо [2].

Задоволеність шлюбом є суттєво пов'язаною із характеристиками стабільності шлюбу, що відображає емоційно та соціально послідовно побудовані стосунки подружжя. Тут основою виступає рівень стійкості шлюбу, тобто соціальна та юридична збереженість шлюбу, небажання парою розлучення. Другим рівнем задоволеності шлюбом виступає адаптованість подружжя, їхня здатність до змін та пристосування в шлюбі. Третій рівень $є$ найглибшим, рівнем успішності шлюбу, який досягається тоді, коли у пари збігаються ціннісні орієнтації в житті [1; 5].

Загалом позитивне ставлення до шлюбу є суб'єктивним сприйняттям подружжям функціонування їхньої сім’ї та її здатність задовольняти їхні індивідуальні потреби, створювати відчуття щастя тощо. Так, науковці, виділяють три групи факторів, що безпосередньо впливають на якість функціонування сім’ї: перша група пов’язана з особистістю членів сім’ї, 
3 ïх вихованням, типом темпераменту. Друга група - стосується передісторії шлюбу й процесом та умовами його виникнення. Третя група - це ті фактори, які проявляються в ході спільного життя пари, такі як побутові питання, характер міжособистісних стосунків тощо [5; 6].

В усіх трьох групах можна виділити фактори, які певним чином впливають на задоволеність шлюбом загалом. Так, серед факторів у першій групі, що мають негативний вплив на позитивне ставлення до шлюбу - виховання в неблагополучній родині, негативне ставлення батьків до цього шлюбу, ранній вік одруження тощо. До факторів другої групи, що негативно впливають на ставлення до шлюбу, відносять короткочасність знайомства до шлюбу, велику різницю у віці між партнерами. Найбільшою є третя група факторів, які відображають особливості відносин у подружжя, що знаходяться у процесі розлучення. Такі сім'і характеризуються сексуальною дисгармонією, несправедливим розподілом роботи по дому, надмірне вживання алкоголю тощо.

Крім цього, шлюбний потенціал пари загалом складається з багатьох факторів: матеріального, соціального, фізичного, культурного, психологічного, сексуального тощо. Так, фізичний фактор носить абсолютно підсвідомий характер. Одна особистість може викликати в іншої абсолютну чи часткову симпатію або антипатію, незважаючи на статеву ідентифікацію. Така індивідуальна й особистісна реакція людини визначається мовою, мімікою, тембром голосу, фізичним виглядом, манерою поводження, жестикуляцією, манерою одягатися, що характерні для окремої людини. Даний фактор визначається ще на перших етапах знайомства та спілкування й відзначається винятковою стійкістю $[1 ; 5]$.

Культурний фактор визначає співвідношення інтелектуальнокультурних потреб та вподобань подружжя. Інтенсивність його $є$ мінливою протягом усього життя навіть однієї пари. Матеріальний фактор створюється співвідношенням грошового внеску партнера в загальний бюджет сім'ї. Тут велике значення має відповідність цього внеску вимогам та очікуванням іншого партнера. Сексуальний фактор позначається відповідністю реальної підсвідомої потреби в інтимної близькості як чоловіка, так і дружини, сексуальним очікуванням від іншого тощо. Цей фактор підлягає багатьом впливам, у тому числі змінам віку, здоров’я, від яких він в першу чергу й залежить $[1 ; 5]$. 
Усі фактори, розглянуті вище, тісно пов'язані між собою, проте особливе місце серед них займає психологічний. Цей фактор центральний, який фокусує на собі усі інші і саме він визначає цілісність та єдність людської поведінки. У шлюбній взаємодії психологічний фактор розуміється як співвідношення особистісних особливостей партнерів, перш за все їхніх рольових домагань, темпераментів та характерів $[3 ; 4 ; 5 ; 6]$.

Таким чином, враховуючи усе вище сказане, можна виділити наступні психологічні особливості позитивного ставлення особистості до шлюбу:

- позитивне відношення один до одного партнерів, що виражається в гармонії при спілкуванні, фізичній, сексуальній, та інтелектуальній привабливості один для одного, збігу цінностей партнерів;

- ефективність спілкування в парі: наявність загальних символів спілкування, глибина або відкриття партнерів, частота конструктивного спілкування в парі, точність розуміння невербальної комунікації, спільність очікувань один від одного, подібність сприйняття ролей у подружньому житті, емпатія та бажання порозумітися;

- емоційна задоволеність стосунками 3 партнером: повага, вираження любові в обидва боки, взаємодопомога особистісному зростанню кожного 3 подружжя, задоволеність рівноправністю стосунків із партнером, виконання кожним його соціально-емоційної ролі, любов до партнера, сексуальна задоволеність, відповідність образу дружини та образу чоловіка, відчуття подружжям себе цілісним - подружньою парою;

- взаємодія, що об'єднує такі фактори задоволеності шлюбом, позитивного до нього ставлення як дружба, спільність діяльності, фізична близькість та ефективність сімейної взаємодії.

Отже, позитивне ставлення особистості до шлюбу відіграє важливу роль у відчутті щастя самою людиною, що виявляється у гармонійному співвідношенні особистісних особливостей партнерів, перш за все їхніх рольових домагань, темпераментів та характерів.

\section{Література:}

1. Андреева Т. В. Семейная психология: учебное пособие. СПб, 2005. 244 c.

2. Безпалько О., Савич Ж. Спілкуємось та діємо: навч.-методичний посібник. Київ, 2002. 112 с. 
3. Практична психологія в системі вищої освіти: теорія, результати досліджень, технології: колективна монографія / H.І. Пов'якель, В.П. Лушин, А.Ф. Федоренко, Т.І. Ханецька та ін.; за редакцією Н.І. Пов'якель. Київ: НПУ імені МП Драгоманова, 2009. 376 с.

4. Трубавіна I. М. Консультування сім'ї: науково-методичні матеріали. Київ, 2003. 88 с.

5. Федорова Т.А., Зеликсон Д.И. Изучение феномена партнерских отношений в зарубежной психологи. Современная зарубежная психология. 2017. Том 6. № 1. С. 60-70.

6. Donnellan M.B., Larsen-Rife D., Conger R.D. Personality, Family History, and Competence in Early Adult Romantic Relationships. Journal of Personality and Social Psychology. 2005. Vol. 88. №. 3. P. 562-576. 